\title{
The effect of mirtazapine on methotrexate-induced toxicity in rat liver
}

\author{
Bunyami Ozogul $^{\mathrm{a}}$, Abdullah Kisaoglu ${ }^{\mathrm{a}}$, Mehmet Ibrahim Turan ${ }^{\mathrm{b}, *}$, Durdu Altuner $^{\mathrm{c}}$, Ebru Sener $^{\mathrm{d}}$, \\ Nihal Cetin ${ }^{\mathrm{e}}$, Cengiz Ozturk ${ }^{\mathrm{e}, \mathrm{f}}$ \\ ${ }^{a}$ Department of Surgery, Faculty of Medicine, Ataturk University, 25240, Erzurum, Turkey \\ b Department of Paediatrics, Faculty of Medicine, Ataturk University, 25240, Erzurum, Turkey \\ c Department of Pharmacology, Faculty of Medicine, Recep Tayyip Erdogan University, 53100, Rize, Turkey \\ ${ }^{d}$ Department of Pathology, Erzurum Region Education and Research Hospital, Erzurum, Turkey \\ e Department of Pharmacology-Toxicology, Faculty of Veterinary Medicine, Ataturk University, 25240, \\ Erzurum, Turkey \\ f Department of Family Medicine, Erzurum State Hospital, Erzurum, Turkey
}

*Corresponding author, e-mail: turan78tr@ hotmail.com

Received 18 Dec 2012

Accepted 20 Mar 2013

\begin{abstract}
Methotrexate is used as a chemotherapeutic agent and its anti-oxidant activity is used to treat many cancer types. This study conducts a biochemical and histopathological investigation into whether mirtazapine has a protective effect on methotrexate-induced hepatotoxicity in rats. Distilled water was given to a healthy group intraperitoneally. Methotrexate alone was injected in the control group, again intraperitoneally. Mirtazapine and, $1 \mathrm{~h}$ later, methotrexate were given to the rats in the final group. This procedure was repeated over 7 days. In the control group rats receiving methotrexate, blood AST, ALT, and LDH levels were $227 \pm 3 \mu \mathrm{mol} / 1,85 \pm 2 \mu \mathrm{mol} / \mathrm{l}$, and $357 \pm 13 \mu \mathrm{mol} / \mathrm{l}$, respectively. In the rats receiving mirtazapine and methotrexate, these values were $152 \pm 3 \mu \mathrm{mol} / \mathrm{l}, 25 \pm 1 \mu \mathrm{mol} / \mathrm{l}$, and $141 \pm 15 \mu \mathrm{mol} / \mathrm{l}$. In the healthy rat group, AST, ALT, and LDH levels were $136 \mu \mathrm{mol} / 1,20 \mu \mathrm{mol} / 1$, and $133 \mu \mathrm{mol} / 1$, respectively. Histopathologically, apoptotic bodies with condensed cytoplasm, peripheral, and pyknotic nuclei in the hepatocytes, focal necrosis and intense inflammation in the interstitial areas were present in the control group. In the methotrexate and mirtazapine group, there were no apoptotic bodies or inflammation, only isolated necrosis in the hepatocytes. In conclusion, mirtazapine protected the liver against methotrexate toxicity.
\end{abstract}

KEYWORDS: drug, hepatotoxicity, oxidant/anti-oxidant

\section{INTRODUCTION}

Methotrexate, a folic acid anti-metabolite, is used as a chemotherapeutic agent for many cancer types (leukaemia, lymphoma, osteosarcoma, head and neck tumours, lung cancer, breast cancer, etc.). Methotrexate is also used for the treatment of multiple sclerosis, dermatomyositis, sarcoidosis, psoriasis, and rheumatoid arthritis, disorders causing inflammation. However, the use of high-dose methotrexate (as in leukaemia) or prolonged use may result in hepatotoxicity that may lead to progressive fibrosis and cirrhosis ${ }^{1}$. Clinically, hepatotoxicity, which occurs in long-term use of methotrexate, remains one of the significant restrictions on its use in the doses desired ${ }^{2}$. Methotrexate inhibits the formation of tetrahydrofolate from folic acid. The inhibition of tetrahydrofolate formation is responsible for both the therapeutic and toxic effects of methotrexate ${ }^{3}$. Although these dele- terious toxic effects of methotrexate can theoretically be reduced or prevented with the addition of folic acid to the treatment, there is as yet no consensus on the subject. On the contrary, there are studies showing that with the addition of folic acid, the therapeutic effectiveness of methotrexate decreases ${ }^{4}$. This indicates that the mechanism of action of methotrexate hepatotoxicity has not yet been fully explained ${ }^{5}$.

Toxicity studies with methotrexate highlight the role of oxidative stress in causing toxicity on the liver and other organs. Levels of both enzymatic and nonenzymatic anti-oxidants are inhibited and the levels of oxidants increase in the liver, kidney, and gut tissues of laboratory animals given methotrexate ${ }^{6}$. It is therefore thought that anti-oxidant therapy may be useful in preventing or reducing hepatotoxicity due to methotrexate. Studies have demonstrated that various anti-oxidants are protective against methotrexate hepatotoxicity. 
Mirtazapine, which we tested for methotrexate hepatotoxicity in our study, is an anti-depressant drug used for the treatment of major depression. Mirtazapine has been shown to inhibit the production of enzymatic and non-enzymatic oxidant parameters, but to increase anti-oxidants in gastric tissue ${ }^{7}$. Our review of the literature elicited no information or interventions regarding the protective effects of mirtazapine on methotrexate-induced oxidative stress in rats. The aim of this study was therefore to investigate, biochemically and histopathologically, whether mirtazapine has a protective effect against methotrexate-induced oxidative stress in the rat liver.

\section{MATERIALS AND METHODS}

\section{Animals}

Thirty male albino Wistar rats weighing between $220 \mathrm{~g}$ and $235 \mathrm{~g}$, provided by the Ataturk University Medical Experimental Practice and Research Centre, were used in the study. Before the experiments, the animals were housed and fed in groups at room temperature $\left(22^{\circ} \mathrm{C}\right)$. Animal experiments were performed in accordance with national guidelines for the use and care of laboratory animals and approved by the local animal care committee of Ataturk University (protocol number: B.30.2.ATA.0.01.02/5388, approval date: 17.11.2011).

\section{Chemical substances}

Of the chemical substances used for the experiments, thiopental sodium was provided by IE UlagayTurkey and mirtazapine was obtained from Organon Pharmaceuticals-USA.

\section{Experimental procedure}

The rats to be used in the experiment were divided into three groups: a control group given methotrexate (MTXC), a group given mirtazapine and methotrexate (MMTX), and a healthy $(\mathrm{H})$ group.

MTXC group rats $(n=10)$ were injected intraperitoneally with $5 \mathrm{mg} / \mathrm{kg}$ methotrexate. The MMTX group $(n=10)$ was given mirtazapine $30 \mathrm{mg} / \mathrm{kg}$ by the oral route; $1 \mathrm{~h}$ after administration of mirtazapine $5 \mathrm{mg} / \mathrm{kg}$ methotrexate was injected intraperitoneally. The $\mathrm{H}$ group was given an equivalent volume of distilled water, using the same technique, by the oral route. Methotrexate was given in a single dose to the MTXC and MMTX groups. The MMTX group was given mirtazapine for 7 days, and the $\mathrm{H}$ group distilled water for 7 days. At the end of this period, all animals were sacrificed using high-dose anaesthesia, their livers were removed and histopathological and biochemical examinations were performed. Histopathological and biochemical data from the mirtazapine group were assessed in comparison with those obtained from the control and healthy groups.

\section{Biochemical analysis}

$A S T, A L T$, and LDH measurements: Venous blood samples were collected into tubes without anticoagulant. Serum was separated by centrifugation after clotting and stored at $-80^{\circ} \mathrm{C}$ until assay. Serum AST and ALT activities as liver function tests, and LDH activity as a marker of tissue injury, were measured spectrophotometrically on a Cobas 8000 (Roche) autoanalyser using commercially available kits (Roche Diagnostics, GmBH, Mannheim, Germany).

MDA, MPO, GSH, and SOD measurements: Following macroscopic analyses, glutathione (GSH), superoxide dismutase (SOD), myeloperoxidase (MPO), and malondialdehyde (MDA) enzyme activities and levels were determined in rat liver tissues. Rat livers were frozen at $-80{ }^{\circ} \mathrm{C}$ until biochemical investigations. To prepare the tissue homogenates, liver tissues were ground with liquid nitrogen in a mortar. The ground tissues $(0.5 \mathrm{~g}$ each $)$ were then treated with $4.5 \mathrm{ml}$ of buffers (consisting of $0.5 \%$ HDTMAB $[0.5 \%$ hexadecyl tri methyl ammonium bromide] $\mathrm{pH}$ : 6 potassium phosphate buffer for MPO analysis, $1.15 \%$ potassium chloride solution for MDA analysis, and $\mathrm{pH}: 7.5$ phosphate buffer for the SOD, GSH analysis). The mixtures were homogenized on ice using an Ultra-Turrax homogenizer for $15 \mathrm{~min}$. Homogenates were filtered and centrifuged using a refrigerated centrifuge at $4{ }^{\circ} \mathrm{C}$. The supernatants were used for the determination of the enzymatic activities. All assays were carried out at room temperature in triplicate.

\section{Total GSH determination}

The amount of GSH in the hepatic mucosa was measured according to the method described by Sedlak and Lindsay apoptotic ${ }^{8}$. The mucosal surface of the liver was collected by scraping, weighed, and then homogenized in $2 \mathrm{ml} 50 \mathrm{mM}$ Tris- $\mathrm{HCl}$ buffer containing $20 \mathrm{mM}$ EDTA and $0.2 \mathrm{mM}$ sucrose, $\mathrm{pH}$ 7.5. The homogenate was immediately precipitated with $0.1 \mathrm{ml}$ of $25 \%$ trichloroacetic acid, and the precipitate was removed by centrifugation at $1380 \mathrm{~g}$ for $40 \mathrm{~min}$ at $4{ }^{\circ} \mathrm{C}$. The supernatant was used to determine GSH using 5,5'-dithiobis(2-nitrobenzoic acid). Absorbance was measured at $412 \mathrm{~nm}$ using a spectrophotometer. GSH 
levels in the mucosa were expressed as nanomoles per milligram of tissue ( $\mathrm{nmol} / \mathrm{mg}$ tissue).

\section{MPO activity}

MPO activity was measured according to the modified method described by Bradley et $\mathrm{al}^{9}$. The homogenized samples were frozen and thawed three times and centrifuged at $1500 \mathrm{~g}$ for $10 \mathrm{~min}$ at $4{ }^{\circ} \mathrm{C}$. MPO activity in the supernatant was determined by adding $100 \mathrm{ml}$ of the supernatant to $1.9 \mathrm{ml}$ of $10 \mathrm{mM}$ phosphate buffer (pH 6.0) and $1 \mathrm{ml}$ of $1.5 \mathrm{mM} o$-dianisidine hydrochloride containing $0.0005 \%$ (wt/vol) hydrogen peroxide. The changes in absorbance at $450 \mathrm{~nm}$ of each sample were recorded on a UV-Vis spectrophotometer. MPO activity in liver tissues was expressed as millimoles per minute per milligram of tissue $\left(\mathrm{mmol} \mathrm{min}^{-1}(\mathrm{mg}\right.$ tissue $)^{-1}$ ).

\section{Determination of lipid peroxidation or MDA formation}

Concentrations of hepatic mucosal lipid peroxidation were determined by estimating MDA using the thiobarbituric acid test ${ }^{10}$. Briefly, the rat livers were promptly excised and rinsed with cold saline. To minimize the possibility of haemoglobin interference with free radicals, any blood adhering to the mucosa was carefully removed. The corpus mucosa was scraped, weighed and homogenized in $10 \mathrm{ml}$ of $100 \mathrm{~g} / \mathrm{l} \mathrm{KCl}$. The homogenate $(0.5 \mathrm{ml})$ was added to a solution containing $0.2 \mathrm{ml}$ of $80 \mathrm{~g} / \mathrm{l}$ sodium lauryl sulphate, $1.5 \mathrm{ml}$ of $200 \mathrm{~g} / \mathrm{l}$ acetic acid, $1.5 \mathrm{ml}$ of $8 \mathrm{~g} / \mathrm{l}$ 2-thiobarbiturate, and $0.3 \mathrm{ml}$ distilled water. The mixture was then incubated at $98^{\circ} \mathrm{C}$ for $1 \mathrm{~h}$. Upon cooling, $5 \mathrm{ml}$ of n-butanol:pyridine (15:1) was added. The mixture was vortexed for $1 \mathrm{~min}$ and centrifuged for $30 \mathrm{~min}$ at $4000 \mathrm{rpm}$. The absorbance of the supernatant was measured at $532 \mathrm{~nm}$. A standard curve was generated using 1,1,3,3-tetramethoxypropane. The recovery was over $90 \%$. The results were expressed as nanomoles MDA per milligram wet tissue (nmol/mg tissue).

\section{Histopathological examination}

The livers removed from the rats were fixed in $10 \%$ formaldehyde. After routine tissue preparation, haematoxylin and eosin sections $5 \mu \mathrm{m}$ in thickness were obtained. Masson's trichrome and reticulin were applied to all sections. Liver lobules and portal areas were examined histopathologically. Representative photomicrographs demonstrate the liver histopathology of test animals.

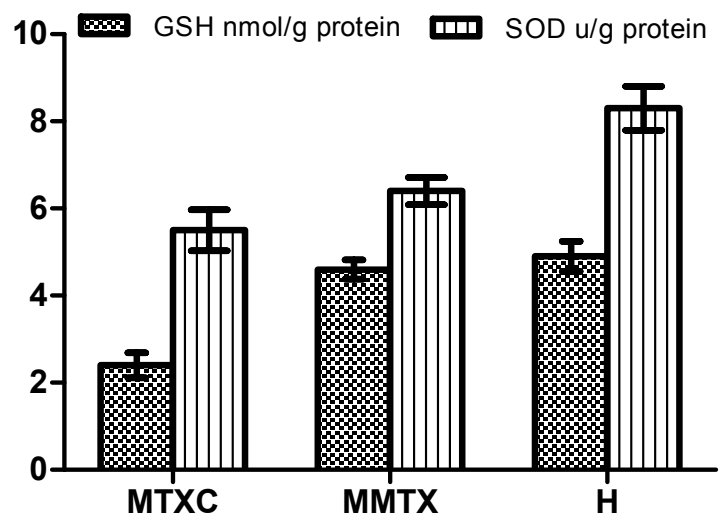

Fig. 1 The GSH level and SOD activity in MMTX, MTXC, and SG rat groups. Results expressed as mean \pm standard error of the mean $(n=10)$.

\section{Statistical analysis}

All data were analysed by one-way ANOVA using SPSS 13.0. Differences among groups were calculated using the least significant difference option, and significance was set at $p<0.05$.

\section{RESULTS}

\section{Biochemical results}

MDA, MPO, GSH, SOD results: As shown in Table 1 and Fig. 1, MDA, MPO, GSH, and SOD levels in the liver tissues of the rats receiving methotrexate in the MTXC group were $7.5 \pm 0.1 \mu \mathrm{mol} / \mathrm{g}$ protein, $3.4 \pm 0.1 \mu \mathrm{mol} / \mathrm{g}$ protein, $2.4 \pm 0.1 \mathrm{nmol} / \mathrm{g}$ protein, and $5.5 \pm 0.2 \mu \mathrm{mol} / \mathrm{g}$ protein, respectively. In the MMTX group, MDA, MPO, GSH, and SOD values were $4.1 \pm 0.2 \mu \mathrm{mol} / \mathrm{g}$ protein $(p<0.001)$, $1.7 \pm 0.1 \mu \mathrm{mol} / \mathrm{g}$ protein $(p<0.001), 4.6 \pm 0.1 \mathrm{nmol} / \mathrm{g}$ protein $(p<0.001)$, and $6.4 \pm 0.1 \mu \mathrm{mol} / \mathrm{g}$ protein $(p<0.001)$, respectively. In the $\mathrm{H}$ group, MDA, MPO, GSH, and SOD levels were $1.9 \pm 0.1 \mu \mathrm{mol} / \mathrm{g}$ protein $(p<0.001), \quad 1.5 \pm 0.1 \mathrm{U} / \mathrm{g}$ protein $(p<$ $0.001), 4.9 \pm 0.1 \mathrm{nmol} / \mathrm{g}$ protein $(p<0.001)$, and $8.3 \pm 0.2 \mathrm{U} / \mathrm{g}(p<0.001)$, respectively.

AST, ALT, LDH results: As shown in Fig. 2 and Fig. 3, blood AST, ALT, and LDH levels in the MTXC group were $227 \pm 3 \mathrm{U} / 1,84.8 \pm 2.3 \mathrm{U} / \mathrm{l}$, and $357 \pm 13 \mathrm{U} / \mathrm{l}$, respectively, compared to $153 \pm 3 \mathrm{U} / \mathrm{l}$ $(p<0.0001), \quad 25.1 \pm 0.8 \mathrm{U} / 1 \quad(p<0.0001)$, and $142 \pm 15 \mathrm{U} / \mathrm{l}(p<0.0001)$ in the MMTX group. In the $\mathrm{H}$ group, AST, ALT, and LDH levels were $135.8 \pm 2.1 \mathrm{U} / 1 \quad(p<0.001), 20.4 \pm 0.9 \mathrm{U} / 1 \quad(p<$ $0.001)$, and $131.4 \pm 1.6 \mathrm{U} / 1(p<0.001)$, respectively. 
Table 1 The MDA level and MPO activity in mirtazapine + methotrexate, methotrexate, and intact rat groups.

\begin{tabular}{lcccc}
\hline & MDA (nmol/mg tissue) & $p$ & MPO $\left(\mathrm{mmol} \mathrm{min}^{-1}(\mathrm{mg} \mathrm{tissue})^{-1}\right)$ & $p$ \\
\hline Mirtazapine $(30 \mathrm{mg} / \mathrm{kg})$ & $4.06 \pm 0.16$ & $<0.0001$ & $1.66 \pm 0.05$ & $<0.0001$ \\
Healthy & $1.91 \pm 0.07$ & $<0.0001$ & $1.51 \pm 0.12$ & $<0.0001$ \\
Control & $7.48 \pm 0.10$ & - & $3.41 \pm 0.08$ & - \\
\hline
\end{tabular}

Results are mean \pm standard error of the mean $(n=10) . p<0.05$ referred as significant versus methotrexate group.

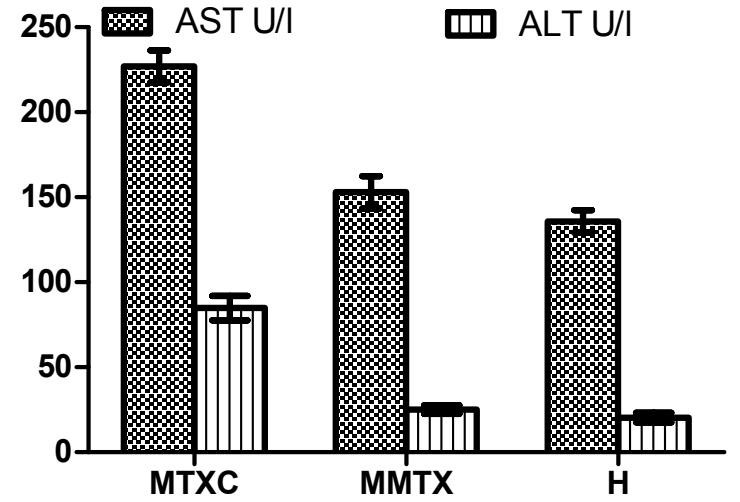

Fig. 2 The AST and ALT activities in MMTX, MTXC and $\mathrm{SG}$ rat groups. Results expressed as mean \pm standard error of the mean $(n=10)$.

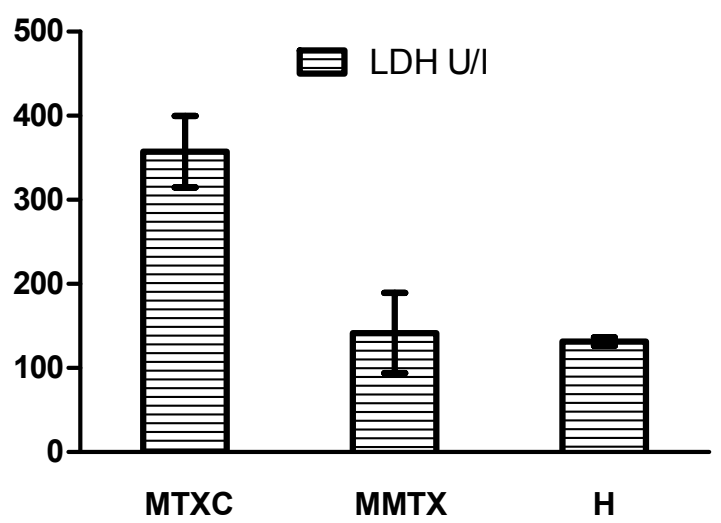

Fig. 3 The LDH levels in MMTX, MTXC and SG rat groups. Results expressed as mean \pm standard error of the mean $(n=10)$.

\section{Pathological findings}

H group liver tissue: Normal hepatic histology was observed in the healthy rat group. There were no pathological signs in the liver lobules or portal areas (Fig. 4).

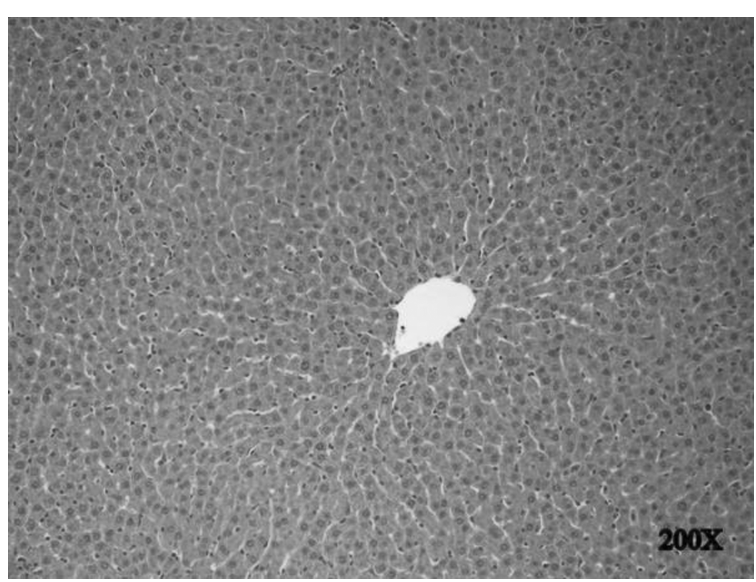

Fig. 4 The histo-pathological examination in the SG group.

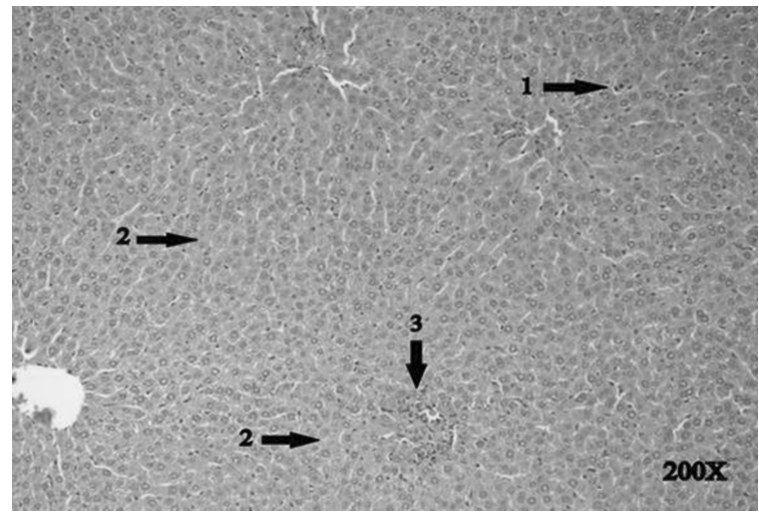

Fig. 5 The histo-pathological examination in the MTXC group. There are apoptotic bodies with condensed cytoplasm, peripheral, and pyknotic nuclei in the hepatocytes (arrow 1), focal necrosis (arrow 2), and intense inflammation in the interstitial areas (arrow 3).

MTXC liver tissue: As seen in Fig. 5, in the MTXC group given methotrexate, we observed apoptotic bodies with condensed cytoplasm, peripheral, and pyknotic nuclei in the liver cells (arrow 1), focal necrosis (arrow 2), and intense inflammation in the interstitial areas (arrow 3). 


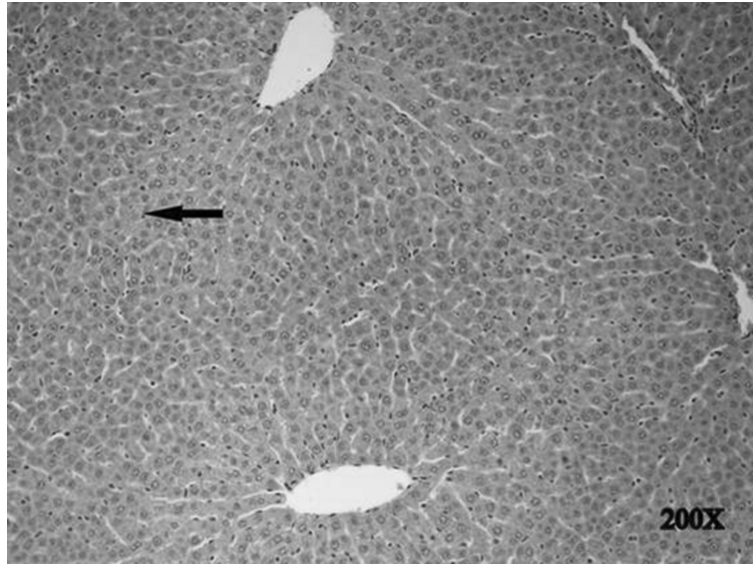

Fig. 6 The histo-pathological examination in the MMTX group. There was isolated necrosis (arrow).

MMTX liver tissue: No apoptotic bodies or inflammation were observed in the MMTX group, only isolated necrosis (Fig. 6).

\section{DISCUSSION}

This study was a biochemical and histopathological investigation of the effect of mirtazapine on methotrexate hepatotoxicity in rats. The results of biochemical tests showed a significant increase in the liver tissue of the MTXC group in the levels of oxidant parameters, e.g., MDA and MPO, and a decrease in anti-oxidant parameters, e.g., GSH and SOD. Oxidative stress is implicated in methotrexate toxicity in the liver ${ }^{11}$. Oxidative stress is an indicator of the damage that results from a change in the balance between oxidants and anti-oxidants in favour of oxidants. Mirtazapine, which we used in our experiment, has been observed to significantly inhibit MDA increase due to methotrexate in the liver. MDA is a 3-carbon aldehyde, the end-product of lipid peroxidation, and is used as a marker of oxidative stress ${ }^{12}$. MDA released after peroxidation of lipids causes irreversible damage to cells and organelle contents ${ }^{13}$. Increased levels of plasma MDA may be attributed to overproduction of reactive oxygen species or a deficiency of antioxidant defence ${ }^{14}$. There are studies showing that MDA levels increase in hepatic injury caused by oxidative stress ${ }^{15}$. The high level of MDA in the MTXC group liver tissue indicates that methotrexate gives rise to oxidative stress in hepatic tissue.

MPO activity in our study was higher in comparison with the $\mathrm{H}$ and MMTX groups in the liver tissues of the animals receiving methotrexate. MPO is released from activated neutrophils and is generally used as a major marker of inflammation ${ }^{16}$. Previ- ous experimental studies with rats have reported that methotrexate increased levels of MPO, a marker of neutrophil infiltration ${ }^{5}$. Another study showed that methotrexate increased MPO activity, a marker of inflammatory response in live and other tissues, in rats $^{6}$. Free radicals lead to activation of neutrophils. Activated neutrophils release extensive amounts of MPO in the tissue areas damaged by free radicals. This situation leads to further exacerbation of tissue damage ${ }^{17}$.

If the delicate balance between oxidants and anti-oxidants cannot be maintained in tissues, many pathological changes extending to cellular damage occur. GSH is an endogenous anti-oxidant, which exists within many cells of the body and protects the functional proteins of the cell against oxidant agents. In our study, mirtazapine significantly eliminated the inhibitor effect of methotrexate on GSH production. Studies in the literature have demonstrated that methotrexate reduces the levels of glutathione in liver cells ${ }^{18}$. A methotrexate-associated fall in glutathione levels leads to hepatocyte injury.

In the present study, SOD activity was significantly lower in the MTXC group in comparison with the MMTX and $\mathrm{H}$ groups. The function of SOD is to catalyse the dismutation of $\mathrm{O}_{2}$ and to protect the tissue against the harmful effects of toxic oxygen radicals ${ }^{19}$. Yagmurca et al demonstrated that SOD activity reduced doxorubicin hepatotoxicity in rats ${ }^{20}$. If oxidative damage is involved in the beginning or pathology of the disease, successful anti-oxidant therapy may prevent the disease occurring or delay its onset.

Our study also ascertained the effects of methotrexate on liver enzymes, e.g., AST, ALT, and LDH. These are associated with hepatocellular injury. ALT and AST are of particular importance in the determination of liver damage. AST, ALT and LDH levels were higher in the MTXC group blood samples in comparison with the MMTX and H groups. Previous studies have showed that methotrexate increases liver enzymes. The serum transaminases have high sensitivity in demonstrating hepatocyte injury. One of the most reliable parameters showing cell destruction in the liver is ALT level ${ }^{21}$. The group with the highest ALT level in this study was the MTXC group, while the MMTX group had the lowest level. AST and ALT have been confirmed as markers of hepatic cell injury ${ }^{22}$. Antioxidants have been shown to prevent severe increases in LDH, AST, ALT and antioxidant parameters in liver injury. In the MTXC group, in which LDH, AST, ALT activities and oxidant parameters were higher, there were apoptotic 
bodies, focal necrosis and intense inflammation in the interstitial areas. In contrast, in the MMTX group there were only a few necrotic cells. Previous studies have also shown that methotrexate intensifies apopto$\operatorname{sis}^{23}$. Caspase is a gene that controls cell apoptosis. Lipid peroxidation established by free radicals has been shown to increase apoptosis by stimulating the caspase gene. Cell apoptosis intensified in hepatic injury induced with methotrexate in rats has been reported $^{24}$. Apoptosis and necrosis may be activated with the same stimuli ${ }^{25}$. In necrosis, cytoplasmic and nuclear contents are released into the intercellular space. Release of cellular contents into intercellular space leads to inflammation. The distinguishing characteristic of this phenomenon is that macrophages and neutrophils migrate to necrotic tissue. These migrating cells cause phagocytosis in necrotic tissues. Inflammation is therefore a significant indicator of necrosis ${ }^{26}$. These findings from the literature are compatible with our own histopathological findings. Mirtazapine blocks 5-HT2 and 5-HT3 receptors with its anti-oxidant property ${ }^{27}$. Stimulation of both 5-HT2 and 5-HT3 receptors is known to be associated with toxic adverse effects ${ }^{28}$.

\section{CONCLUSIONS}

Methotrexate led to oxidative stress in the rat liver, while mirtazapine significantly prevented methotrexate-induced oxidative stress. This shows that the desired dose of methotrexate can safely be used with mirtazapine in the treatment of cancer and non-cancer diseases.

Acknowledgements: This study was supported by the Scientific Research Project of Ataturk University-BAP 2005/160-2008/126. We thank Prof. Fatih Akcay for his contributions to this study.

\section{REFERENCES}

1. Hytiroglou P, Tobias H, Saxena R, Abramidou M, Papadimitriou CS, Theise ND (2004) The canals of hering might represent a target of methotrexate hepatic toxicity. Am J Clin Pathol 121, 324-9.

2. Sener G, Eksioglu-Demiralp E, Cetiner M, Ercan F, Yegen BC (2006) Beta-glucan ameliorates methotrexate-induced oxidative organ injury via its antioxidant and immunomodulatory effects. Eur J Pharmacol 542, $170-8$.

3. Jolivet J, Cowan KH, Curt GA, Clendeninn NJ, Chabner BA (1983) The pharmacology and clinical use of methotrexate. New Engl J Med 309, 1094-104.

4. Whittle SL, Hughes RA (2004) Folate supplementation and methotrexate treatment in rheumatoid arthritis: a review. Rheumatology 43, 267-71.
5. Cetinkaya A, Bulbuloglu E, Kurutas EB, Kantarceken B (2006) N-acetylcysteine ameliorates methotrexateinduced oxidative liver damage in rats. Med Sci Monit 12, 274-8.

6. Jahovic N, Cevik H, Sehirli AO, Yegen BC, Sener G (2003) Melatonin prevents methotrexate-induced hepatorenal oxidative injury in rats. J Pineal Res 34, 282-7.

7. Bilici M, Ozturk C, Dursun H, Albayrak F, Saglam MB, Uyanik A, Gulaboglu M, Tekin SB (2009) Protective effect of mirtazapine on indomethacin-induced ulcer in rats and its relationship with oxidant and antioxidant parameters. Dig Dis Sci 54, 1868-75.

8. Sedlak J, Lindsay RH (1968) Estimation of total, protein-bound, and nonprotein sulfhydryl groups in tissue with Ellman's reagent. Anal Biochem 25, 192-205.

9. Bradley PP, Priebat DA, Christensen RD, Rothstein G (1982) Measurement of cutaneous inflammation: estimation of neutrophil content with an enzyme marker. J Investig Dermatol 78, 206-9.

10. Ohkawa H, Ohishi N, Yagi K (1979) Assay for lipid peroxides in animal tissues by thiobarbituric acid reaction. Anal Biochem 95, 351-8.

11. Devrim E, Cetin R, Kilicoglu B, Erguder BI, Avci A, Durak I (2005) Methotrexate causes oxidative stress in rat kidney tissues. Ren Fail 27, 771-3.

12. Cighetti G, Duca L, Bortone L, Sala S, Nava I, Fiorelli G, Cappellini MD (2002) Oxidative status and malondialdehyde in $\beta$-thalassaemia patients. Eur J Clin Investig 32, Suppl 1, 55-60.

13. Gutteridge JM (1995) Lipid peroxidation and antioxidants as biomarkers of tissue damage. Clin Chem 41, 1819-28.

14. Amirkhizi F, Siassi F, Minaie S, Djalali M, Rahimi A, M, C (2008) Assessment of lipid peroxidation and activities of erythrocyte cytoprotective enzymes in women with iron deficiency anemia. J Res Med Sci 13, 248-54.

15. Matos HR, Capelozzi VL, Gomes OF, Di Mascio P, Medeiros MHG (2001) Lycopene inhibits DNA damage and liver necrosis in rats treated with ferric nitrilotriacetate. Arch Biochem Biophys 396, 171-7.

16. Song M, Song Z, Barve S, Zhang J, Chen T, Liu M, Arteel GE, Brewer GJ, McClain CJ (2008) Tetrathiomolybdate protects against bile duct ligation-induced cholestatic liver injury and fibrosis. J Pharmacol Exp Therapeut 325, 409-16.

17. Sullivan GW, Sarembock IJ, Linden J (2000) The role of inflammation in vascular diseases. J Leukoc Biol 67, 591-602.

18. Babiak RM, Campello AP, Carnieri EG, Oliveira MB (1998) Methotrexate: pentose cycle and oxidative stress. Cell Biochem Funct 16, 283-93.

19. Fridovich I (1995) Superoxide radical and superoxide dismutases. Annu Rev Biochem 64, 97-112.

20. Yagmurca M, Bas O, Mollaoglu H, Sahin O, Nacar A, Karaman O, Songur A (2007) Protective effects of erdosteine on doxorubicin-induced hepatotoxicity in 
rats. Arch Med Res 38, 380-5.

21. Hamanoue M, Kawaida K, Takao S, Shimazu H, Noji S, Matsumoto K, Nakamura T (1992) Rapid and marked induction of hepatocyte growth factor during liver regeneration after ischemic or crush injury. Hepatology 16, 1485-92.

22. Desai SP, Isa-Pratt S (2004) Clinician's Guide to Laboratory Medicine. Chapter 66. Lexi-Comp Inc. pp 612-3.

23. Horie T, Li T, Ito K, Sumi S, Fuwa T (2006) Aged garlic extract protects against methotrexate-induced apoptotic cell injury of IEC-6 cells. $J$ Nutr 136, 861S-3S.

24. Demiryilmaz I, Sener E, Cetin N, Altuner D, Suleyman B, Albayrak F, Akcay F, Suleyman H (2012) Biochemically and histopathologically comparative review of thiamine's and thiamine pyrophosphate's oxidative stress effects generated with methotrexate in rat liver. Med Sci Monit 18, 475-81.

25. Bonfoco E, Krainc D, Ankarcrona M, Nicotera P, Lipton SA (1995) Apoptosis and necrosis: two distinct events induced, respectively, by mild and intense insults with N-methyl-D-aspartate or nitric oxide/superoxide in cortical cell cultures. Proc Natl Acad Sci Unit States Am 92, 7162-6.

26. Schwartzman RA, Cidlowski JA (1993) Apoptosis: the biochemistry and molecular biology of programmed cell death. Endocr Rev 14, 133-51.

27. Ağargün MY, Ebrinç S (1998) Mirtazapine: a review. Bull Clin Psychopharmacol 8, 59-68.

28. Frazer A (1994) Antidepressant drugs. Depression 2, $1-19$. 